DOI https://doi.org/10.15589/znp2021.2(485).6

УДК 629.5.04: 629.5.048

\title{
MODELING MICROCLIMATE OF SHIP PREMISES IN MATLAB-SIMULINK
}

\section{МОДЕЛЮВАННЯ МІКРОКЛІМАТУ СУДНОВОЇ НАДБУДОВИ B MATLAB-SIMULINK}

\author{
Viktor A. Bily \\ bily.viktor@gmail.com \\ ORCID: 0000-0001-6354-0790 \\ Volodymyr A. Golikov \\ vlad.ant.golikov@gmail.com \\ ORCID: 0000-0002-9953-2116
}

\author{
В. А. Білий, \\ аспірант \\ В. А. Голіков, \\ докт. техн. наук, професор
}

\author{
National University “Odesa Maritime Academy”, Odesa \\ Національний університет «Одеська морська академія», м. Одеса
}

\begin{abstract}
Purpose. Improvement of the crew safety and comfort requires a study of temperature, humidity and indoor air quality dynamics. The purpose of the study is to develop a modeling technique that will allow to synthesize a model of the microclimate of the ship superstructure as a continuous hierarchical dynamic system. The structural elements of the system being modeled are interconnected air chambers: premises and air ducts. Mathematical description of air tanks should allow modelling of the indoor air temperature, humidity and gas composition dynamics.

Method. The study utilizes methods of abstraction, system analysis, comparison and synthesis. The object of the study is the microclimate of the ship's superstructure. The subject of the study is modeling of air temperature, humidity and gas composition the dynamics. The superstructure is considered to be a set of rooms connected by supply and exhaust air ducts. The corresponding elements of the moist air subsystem of the Matlab-Simulink software package were used for modeling of premises and air ducts.

Results. Structural identification of the control object has been performed. Existing mathematical models, approaches and systems of microclimate modeling are analyzed. A method of modeling on the basis of the humid air subsystem of the Matlab-Simulink software package using the design documentation of the central air conditioning system and superstructure drawings is proposed. The method has been applied to the synthesize the model of the gas carrier superstructure microclimate. As a result of modeling, the acceleration curves of the average temperature and average humidity of the ship's superstructure were calculated. The adequacy of the obtained model is shown.

Scientific novelty. The proposed method allows to synthesize a model of the microclimate of the superstructure of any vessel and to investigate the characteristics of the system that were not taken into account during the design of the vessel, to implement and improve the use of centralized and distributed filtration systems and automatic air control.

Practical importance. The application of the technique allows to improve and develop filtration systems and control systems for the preparation and distribution of superstructure air both at the design stage of the vessel and during its operation.
\end{abstract}

Key words: safety; microclimate; indoor air quality; modeling; comfort.

Анотація. Мета. Підвищення безпеки життєдіяльності та комфорту екіпажів морських та річкових суден потребує дослідження динаміки температури, вологості та вмісту забрудненості в повітрі приміщень. Метою дослідження є розробка методики моделювання, яка дозволить синтезувати модель мікроклімату надбудови судна як неперервної ієрархічної динамічної системи. Структурними елементами системи, що моделюється, виступають взаємопов’язані повітряні ємності - приміщення та повітропроводи. Математичний опис повітряних ємностей має забезпечувати можливість дослідження динаміки температури, вологості та газового складу повітря.

Методика. Під час проведення дослідження застосовувались методи абстрагування, системного аналізу, порівняння, синтезу. Об'єктом дослідження є мікроклімат приміщень суднової надбудови. Предметом дослідження є моделювання динаміки температури, вологості та газового складу повітря. Надбудова судна розглядається як 


\section{АВТОМАТИЗАЦІЯ ТА КОМП'ЮТЕРНО-ІНТЕГРОВАНІ ТЕХНОЛОГІЇ №2 - 2021}

сукупність приміщень, пов'язаних між собою повітропроводами припливного та вихідного повітря. Для моделювання приміщень та повітропроводів були використані відповідні елементи підсистеми вологого повітря програмного пакету Matlab-Simulink.

Результати. Здійснено структурну ідентифікацію об’єкта керування. Проаналізовано наявні математичні моделі, підходи й системи моделювання мікроклімату. Запропоновано методику моделювання на базі підсистеми вологого повітря програмного пакету Matlab-Simulink з використанням проєктної документації центральної системи кондиціювання та креслень надбудови. Методику застосовано до синтезу моделі мікроклімату надбудови судна-газовозу. В результаті моделювання були розраховані криві розгону середньої температури та середньої вологості повітря приміщень надбудови судна. Показана адекватність отриманої моделі.

Наукова новизна. Запропонована методика дає змогу синтезувати модель мікроклімату надбудови будь-якого судна та досліджувати характеристики системи, які не були враховані під час проєктування судна, впроваджувати та підвищувати ефективність використання централізованих та розподілених систем фільтрації та автоматичного управління підготовкою повітря.

Практична значимість. Застосування методики дозволяє розробляти системи фільтрації та системи управління підготовкою та розподіленням повітря надбудови як на стадії проєктування судна, так і під час його експлуатації.

Ключові слова: безпека життєдіяльності; мікроклімат; якість повітря приміщень; моделювання; комфортність.

\section{ПОСТАНОВКА ЗАДАЧІ}

Морський та річковий транспорт характеризується єдністю умов праці та проживання й тривалим знаходженням екіпажу під впливом шкідливих факторів протягом рейсу. Суднові технічні засоби як створюють потрібні умови для перебування екіпажу на борту, так і можуть на них впливати. Протягом експлуатації судна відбувається акумуляція шкідливих речовин в повітрі приміщень. Це небезпечно для людини через знаходження іiі під впливом забруднювачів тривалий час без перерв. У зоні ризику знаходяться, зокрема, екіпажі суден, що перевозять небезпечні вантажі, такі як танкери-хімовози [1] та танкери-газовози. Проблема незадовільної якості повітря у приміщеннях також актуальна для пасажирських суден $[1 ; 2 ; 3]$. Джерелом забруднення виступають як матеріали конструкції та оздоблення приміщень [4], так і недоліки побудови систем вентиляції, через які викиди з двигунів потрапляють у припливне повітря [5]. Стаціонарні газовимірювальні системи є обов'язковими лише для суден танкерного флоту, вони призначені для забезпечення вибухонебезпечності судна та не виявляють формальдегід, озон, забруднювачі, що є складовими вихлопних газів, зокрема оксид вуглецю, оксиди азоту й сірки, тверді частинки сажі тощо.

Для забезпечення оптимальної працездатності моряків та безпеки пасажирів параметри повітря житлових та виробничих приміщень мають підтримуватися в безпечних та комфортних межах. Створення систем автоматичного керування якістю та комфортністю повітря й дослідження їх ефективності потребує синтезу математичної моделі мікроклімату суднової надбудови як об’єкта керування температурою, вологістю та газовим складом повітря.

\section{АНАЛІЗ ОСТАННІХ ДОСЛІДЖЕНЬ І ПУБЛІКАЦЙ}

Для моделювання динаміки параметрів повітря приміщень існують декілька підходів.
Математична модель мікроклімату суднового приміщення 3 зосередженими параметрами у вигляді системи звичайних диференціальних рівнянь відносно чотирьох змінних - температури, вологості, швидкості потоку повітря та температури огороджувальних поверхонь - запропонована у роботі В.А. Голікова [6].

У своїй роботі К.В. Ходарина [7] розвила дослідження В.А. Голікова й використала операторну форму системи звичайних диференціальних рівнянь для дослідження процесів стабілізації інтегрального показника комфортності мікроклімату.

Автори A. Ryzhov, H. Ouerdane, E. Gryazina [8] використали спрощену модель мікроклімату приміщення у вигляді системи лінійних диференційних рівнянь відносно температури повітря приміщення та ефективної температури інерційних мас огороджень для оптимізації управління за методом Прогностичного Контролю (Model Predictive Control).

J. Schijndel [9] провів дослідження 25 методик імітаційного моделювання динаміки теплопередачі та параметрів повітря приміщень, більшість 3 яких пройшли верифікацію та перевірку шляхом натурного експерименту. У роботі показані переваги моделювання мікроклімату приміщень з використанням пакету MatlabSimulink, який дозволяє будувати моделі на базі звичайних диференціальних рівнянь і включає бібліотеки готових структурних блоків, інструменти ідентифікації об'єктів керування та оптимізації систем управління.

У дослідженні [10] показані перспективи використання підсистеми вологого повітря програмного пакету Matlab-Simulink для моделювання динаміки газового складу, температури й відносної вологості повітря окремого виробничого приміщення.

\section{ВІДОКРЕМЛЕННЯ НЕ ВИРІШЕНИХ РАНІШЕ ЧАСТИН ЗАГАЛЬНОЇ ПРОБЛЕМИ}

Аналіз останніх досліджень показав потребу в створенні методики моделювання мікроклімату, що 
дозволить досліджувати динаміку параметрів повітря окремих приміщень, палуб та надбудови судна в цілому.

\section{МЕТА ДОСЛІДЖЕННЯ}

Метою дослідження є розробка методики моделювання, яка дозволить синтезувати модель мікроклімату надбудови судна як неперервної ієрархічної динамічної системи. Структурними елементами системи, що моделюється, є взаємопов'язані повітряні ємності - приміщення та повітропроводи. Математичний опис повітряних ємностей має забезпечувати можливість дослідження динаміки температури, відносної вологості та газового складу повітря.

\section{МЕТОДИ, ОБ'СКТ ТА ПРЕДМЕТ ДОСЛІДЖЕННЯ}

Об’єктом дослідження є мікроклімат приміщень суднової надбудови. Предметом дослідження є моделювання динаміки температури, відносної вологості та газового складу повітря.

Дослідження проводилось 3 використанням системного підходу й методів абстрагування, системного аналізу, порівняння, синтезу.

\section{ОСНОВНИЙ МАТЕРІАЛ}

Застосування системного підходу дає можливість розглядати мікроклімат суднової надбудови як відкриту динамічну систему, що складається з елементів і підсистем - декількох палуб, установки кондиціювання повітря та магістральних повітропроводів, що їх з'єднують між собою. Палуби як підсистеми містять сукупність суміжних приміщень та повітропроводів припливного та вихідного повітря.

Кількісний опис досліджуваної системи потребує виділення сукупності параметрів та характеристик.

Параметри описують властивості системи і є початковими даними для аналізу системи. До них слід віднести:

- геометричні розміри приміщень, повітропроводів та їх топологію;

- розрахункові масові витрати припливного повітря для кожного приміщення;

- площу та теплопровідність зовнішніх огороджень надбудови;

- холодильну потужність та масову витрату повітря установки кондиціювання повітря.

Характеристики описують вторинні властивості системи, які визначаються розв'язанням задачі аналізу і є функціями параметрів та чинників впливу середовища. Мікроклімат надбудови характеризується температурою, відносною вологістю та газовим складом повітря іiї приміщень.

Чинниками впливу навколишнього середовища на досліджувану систему $є$ температура, вологість і газовий склад зовнішнього повітря та теплообмін через зовнішні огородження.

Для синтезу моделі мікроклімату надбудови згідно з зазначеними вимогами може бути використана методика, яку складають такі процедури:

1) синтез структури моделі надбудови як сукупності палуб-підсистем, а також установок кондиціювання повітря, пов'язаних головними повітропроводіами;

2) синтез моделей палуб-підсистем шляхом відтворення топології приміщень та повітропроводів з урахуванням їх геометричних розмірів згідно з кресленнями надбудови та документацією центральної системи кондиціювання. Якщо для цілей дослідження достатньо усереднених значень температури, вологості та концентрацій забруднювача групи однотипних приміщень деякої палуби, то їх доцільно апроксимувати результівними ємностями;

3) деталізація моделі палуби й моделювання окремих приміщень як підсистем в разі потреби у дослідженні динаміки параметрів повітря в цих приміщеннях;

4) моделювання теплового обміну приміщень кожної палуби з навколишнім середовищем;

5) моделювання потоку тепла та водяної пари від мешканців;

6) синтез моделі установки кондиціювання повітря з урахуванням іï потужності та масової витрати повітря;

7) первинна перевірка адекватності отриманої моделі шляхом порівняння розрахунків масової витрати, температури та відносної вологості повітря 3 проєктними значеннями.

Запропонована методика була застосована для моделювання мікроклімату надбудови газовозу LPG/C “Epic Corsica" у середовищі Matlab-Simulink 3 використанням проєктних параметрів системи кондиціювання та вентиляції (табл. 1). Надбудова досліджуваного судна (рис. 1) складається з трьох палуб та ходового містка. Кожна палуба містить приміщення двох типів - закритого (AIR CON у табл. 1) та відкритого (SPOT у табл.1). Повітря з приміщень закритого типу повертається у систему кондиціювання. Повітря з приміщень відкритого типу вентилюється назовні. Ходовий місток містить одне приміщення відкритого типу. Літній тепловий потік через зовнішні огородження приміщень наведено для зовнішнього повітря з температурою $35^{\circ} \mathrm{C}$ та відносною вологістю 70\% й внутрішнього повітря 3 температурою $27^{\circ} \mathrm{C}$ та відносною вологістю 50\%. Зимовий тепловий потік наведено для зовнішнього повітря з температурою $-20^{\circ} \mathrm{C}$ та відносною вологістю $30 \%$ та внутрішнього повітря з температурою $20^{\circ} \mathrm{C}$ та відносною вологістю $50 \%$.

При синтезі моделі кожної з палуб (рис. 2) усі приміщення закритого типу представлені результівною ємністю «Каюти», а всі приміщення відкритого типу (душові та санвузли) - результівною ємністю «Санвузли». Об’єми результівних ємностей дорівнюють сумі об'ємів приміщень відповідного типу згідно 3 таблицею 1. 


\section{АВТОМАТИЗАЦІЯ ТА КОМП'ЮТЕРНО-ІНТЕГРОВАНІ ТЕХНОЛОГІЇ №2 2021}

Таблиця 1. Параметри приміщень надбудови газовозу LPG/C “Epic Corsica”

\begin{tabular}{|c|c|c|c|c|c|c|c|c|c|c|c|c|c|c|c|c|c|c|c|}
\hline \multirow[b]{2}{*}{ DK } & \multicolumn{2}{|r|}{ SPACE } & \multicolumn{2}{|c|}{ ROOM VOL. } & \multicolumn{2}{|c|}{$\begin{array}{l}\text { VENTILATION } \\
\text { IAIR }\end{array}$} & \multirow[b]{2}{*}{ MEN } & \multicolumn{3}{|c|}{ SUMMER } & \multicolumn{2}{|c|}{ HINTER } & \multicolumn{2}{|c|}{ FRESH AIR } & \multicolumn{2}{|c|}{ FINAL AIR VOL. } & \multicolumn{3}{|c|}{ AIR DIFFUSER } \\
\hline & No. & ROOM NAME & $\begin{array}{l}\text { AIR } \\
\text { CoN. } \\
\mathrm{m}^{3}\end{array}$ & $\begin{array}{l}\mathrm{SPOT} \\
\mathrm{n}^{3}\end{array}$ & $\begin{array}{l}A \mid R \\
T / H\end{array}$ & $\begin{array}{l}\text { AIR } \\
\text { voLUME } \\
\mathrm{m}^{3} / \mathrm{H}\end{array}$ & & $\begin{array}{c}\text { HEAT GAI } \\
\text { SENSIBLE }\end{array}$ & $\frac{N \text { [ [m] }}{\text { LATENT }}$ & $\begin{array}{l}\text { AIR VOL. } \\
n^{3} / \mathrm{H}\end{array}$ & $\begin{array}{l}\text { HERT } \\
\text { LOSS. } \\
\text { [W] }\end{array}$ & $\begin{array}{l}\text { AIR VOL. } \\
m^{3} / H\end{array}$ & $\begin{array}{l}\text { NECESS. } \\
\mathrm{m}^{3} / \mathrm{H}\end{array}$ & $\begin{array}{l}\text { ACTUAL } \\
\mathrm{m}^{3} / \mathrm{H}\end{array}$ & $\mathrm{m}^{3 / \mathrm{H}}$ & $T / H$ & TYPE & SIZE & No. \\
\hline & & BHEEL HOUSE. & & 91.5 &. .10 & 9150 & & & & & & & 274.5 & 274.5 & 915 & & PI & & \\
\hline DK.TOIAL & & & 00 & 91.5 & & 9150 & & & & & & & 274.5 & 274.5 & 915 & 10.0 & & & \\
\hline APY. & & HOSPTTAL & & & & & & & & & & & & & 04 & & & & \\
\hline & & $20 \mathrm{EF}$ - & -14 & & & 85.8 & $\ldots$ & 630 & 73 & 18 & 684 & 120 & 5 & 564 & & & & & \\
\hline CAPY. & & CAPY BEE RU & 10 & & & 606 & $\ldots$ & 2894 & 733 & & -292. & -51 & & 25 & & & & & \\
\hline CAPY & & $\begin{array}{l}\text { CaPT RI } \\
\text { Pltor }\end{array}$ & $\frac{19}{12}$ & & & 14.6 & & 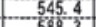 & 73.3 & & & 22. & & 48 & & & & & \\
\hline CAPY & & 3/OFF. & 130 & & & 5 & & -531.5 & $-73 \cdot 3$ & $\frac{1753}{158}$ & $\begin{array}{r}6386 \\
4943\end{array}$ & $\frac{1}{87}=\frac{8}{3}$ & 47 & 526 & & & & & \\
\hline & & HOSP LAV & & 81 & & & & & & & & & & $\frac{41.3}{12}$ & & & & & \\
\hline CAPY & & CAPT LAY & & 86 & & 43.0 & 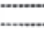 & & & & & & 12 & 129 & & & & & \\
\hline CAPY & & SHOWER & & 6.4 & & 32.0 & & & & & & & & & & & & & \\
\hline CAPI. & & U. C1 & & 6.2 & & & & & & & 143.4 & 25.4 & & & & & & 3.5 & \\
\hline OK TOTAL & $\ldots$ & & 87.0 & 29.3 & & 637.5 & & 3269.1 & 440.0 & 9740 & .3514 .7 & 620.8 & 327.0 & 334.6 & 1115 & & & & \\
\hline & & SSPARE & 118 & & & & & 53 & 733 & & 597.0 & 1054 & & 47.7 & & & & & \\
\hline & & $\tan (1)$ & 100 & & & & & -310 & -733 & & $\begin{array}{r}3287 \\
\cdots .35 \%\end{array}$ & $\begin{array}{c}581 \\
68-1\end{array}$ & & & & & & & \\
\hline & & $\operatorname{sos} 2$ & 113 & & & & & $\begin{array}{r}441.6 \\
3628\end{array}$ & $\begin{array}{r}13 \\
73.3 \\
\end{array}$ & & $\begin{array}{r}3652 \\
464-0\end{array}$ & 82.8 & 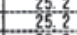 & $\begin{array}{r}39.5 \\
33.4 \\
-39\end{array}$ & & & & 45 & \\
\hline & & CENG & 132 & & $\ldots$ & & & $\begin{array}{r}3153 \\
-353 \\
-35\end{array}$ & -73.3 & 100 & $\begin{array}{r}3186 \\
-250\end{array}$ & -563 & & 28.2 & & & & & \\
\hline & & 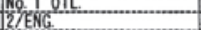 & 13.2 & & -6 & & & 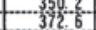 & $-\frac{3}{73} \cdot \frac{3}{3}$ & -111. & -466 - & 82.4 & & & & & & $45^{\circ}$ & \\
\hline & & 3/ENG & 130 & & $\ldots$ & 780 & & 3043 & 73.3 & 907 & 2727 & $\frac{86}{48.2}$ & & & & & & & \\
\hline & & $62 \times(3)$ & 120 & & & 720 & & 4461 & 73.3 & 1329 & 4723 & 834 & & 39.9 & & & & 45 & \\
\hline & & CTENG LAV & & 11. 1 & & 55.5 & & & & & & & & 167 & & & & & \\
\hline BOA $\cdots$ & & 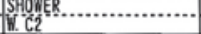 & $\cdots$ & 10.4 & $\cdots \cdot 1$ & $0=0.70 .0$ & & ....... & $\cdots$ & ....... & $=3700 \%$ & 65.6 & 8 & . 19.6 .7$. & . & 2 & & .3 .5 & \\
\hline DK TOIAL & & & .104 .1 & 28.1 & & 7.121 & & 3437.4 & 650.0 & 10241 & 4305.4 & 760.7 & 253.1 & 353.3 & 1178 & & & & \\
\hline 6005 & & TCRETS MESS & 335 & & $\ldots$ & 2680 & & -1847.2 & 5129 & 5504 & 21228 & 3749 & 1260 & 1651 & & 16. & Pt & & \\
\hline pop & & SAI (A) & 100 & & & 600 & & 571.6 & $\ldots$ & -1703 & 789 & 1395 & & 5 & & & & & \\
\hline p & 26, & 11 ENG & $\begin{array}{r}15.7 \\
1\end{array}$ & & - & $54 \quad 94$ & & $\begin{array}{r}923.3 \\
-3.5\end{array}$ & $\frac{73.3}{72}$ & $\begin{array}{r}2751 \\
-141\end{array}$ & $\begin{array}{r}12992 \\
-632\end{array}$ & -229.5 & & & $\frac{75}{41}$ & & & & \\
\hline & 28 & POFFTCE & 13.6 & & & $\begin{array}{l}62 \\
51.6 \\
51.6\end{array}$ & & $\frac{43.6}{604.4}$ & $\frac{7.3}{73.3}$ & $\frac{41.1}{180.1}$ & $\begin{array}{r}633.4 \\
840.7\end{array}$ & $\begin{array}{r}111.9 \\
148.5\end{array}$ & $-\frac{25.2}{25.2}$ & 54.3 & $\frac{141}{180}$ & & & & \\
\hline & & C7OFF & 163 & & & 69.8 & & 9487 & 733 & 2827 & 13325 & 2354 & $\ldots 2$ & 848 & $\ldots \ldots$ & 17 & $\mathrm{PL}$ & & \\
\hline & & SAILI C. & 104 & & $\ldots$ & 6.62 .4 & & -597.7 & $\begin{array}{r}733 \\
75-3\end{array}$ & -1781 & 8346 & 147.4 & -252 & 53.4 & $\ldots .178$ & & & & \\
\hline & & OOFFTEER MESS I SACOON & $-\frac{10}{38.6}$ & & & $8-308.8$ & & $\begin{array}{r}154.5 \\
1378\end{array}$ & 586.3 & $\begin{array}{r}153.3 \\
410.7\end{array}$ & 1065.7 & $\begin{array}{r}18.4 \\
-188.2 \\
\end{array}$ & $\begin{aligned} 25.2 \\
-1360\end{aligned}$ & 136.0 & 453 & $\frac{150}{11.7}$ & pt & & \\
\hline & & GAiter & & & -1 & 0.350 & & & & & & & 94.5 & 945 & 15 & -100 & sh. & & \\
\hline 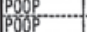 & $-\frac{34}{35}$ & SHOWER & & & & $\begin{array}{l}5 \\
0\end{array}-\frac{39}{0.5}$ & & & & & $=0$ & 367 & 11.99 & -11.9 & 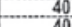 & -5.0 & PL. & & \\
\hline DK TOTALI & 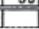 & 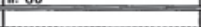 & 158.7 & $\frac{10.3}{49.7}$ & & 1450.9 & & 859.3 & 1612.4 & 2341.8 & $\frac{66.8}{9864.0}$ & 1742.4 & 1.5 & 833.5 & $\frac{40}{779}$ & & & & \\
\hline
\end{tabular}

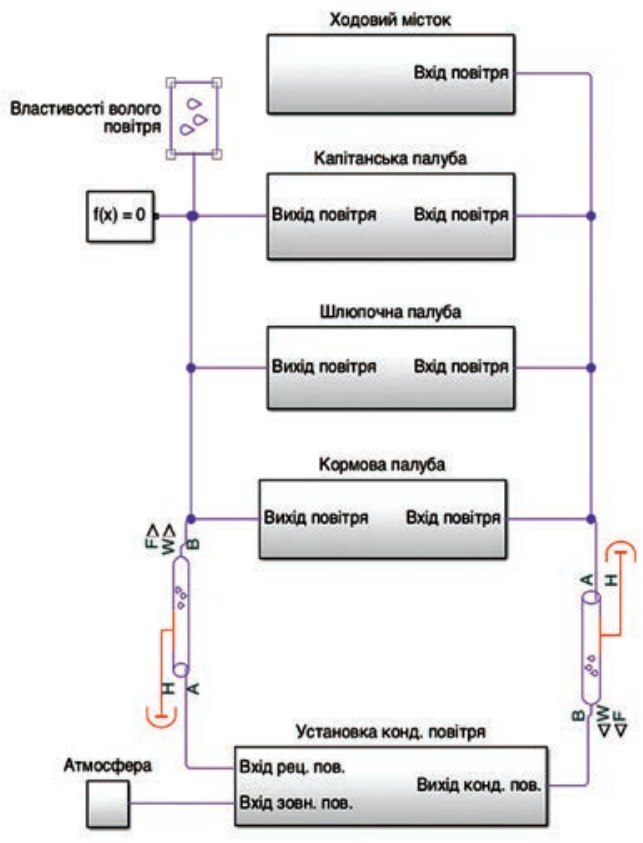

Рис. 1. Модель надбудови газовозу LPG/C “Epic Corsica”

Для моделювання динаміки параметрів повітря та вмісту забруднювача в окремому приміщенні потрібна подальша деталізація моделі та представлення досліджуваної каюти як підсистеми, пов'язаної теплота масообміном з іншими приміщеннями (рис. 3).

На тепловий та масовий баланс приміщення впливають обмін з навколишнім середовищем та теплота й волога, що виділяються організмом людини (рис. 4).

Тепловий потік $\mathrm{Q}_{л}$ та масова витрата водяної пари людини $\mathrm{G}_{л}$ залежать від іï активності та вдягненості. Для цілей даної роботи ці параметри прийняті постійними: $\mathrm{G}_{\mathrm{r}}=0.02$ г/с, $\mathrm{Q}_{\mathrm{s}}=80$ Вт, що відповідає швидкості метаболізму 1 MEТ легко вдягненої людини, що сидить.

Згідно 3 конструкцією судна модель ходового містка (рис. 5) не має повітропроводу для повернення повітря у систему кондиціювання. Обмін повітря здійснюється шляхом надходження припливного повітря через дифузори та випуск його в атмосферу через вентиляційний отвір.

Модель установки кондиціювання повітря (рис. 6) синтезована згідно з документацією суднової СКП. Вона складається з камери змішування, вентилятора та випарника. Камера змішування має вхідні отвори для зовнішнього та рециркуляційного повітря, а ii вихід з'єднаний з випарником. Після випарника повітря потрапляє у повітряний простір корпусу кондиціонера, в якому знаходиться вентилятор з ремінним приводом та електродвигуном потужністю 5.5 кВт. Повітряний простір відокремлений горизонтальною перегородкою від двох компресорів потужністю 7.5 кВт, конденсатора та з'єднувальних трубопроводів. Частка теплових втрат наведеного вище обладнання потрапляє до повітряного простору. Ці витрати представлені сумарним тепловим потоком у 3300 Вт, який призводить до зростання температури припливного повітря на $2^{\circ} \mathrm{C}$. 


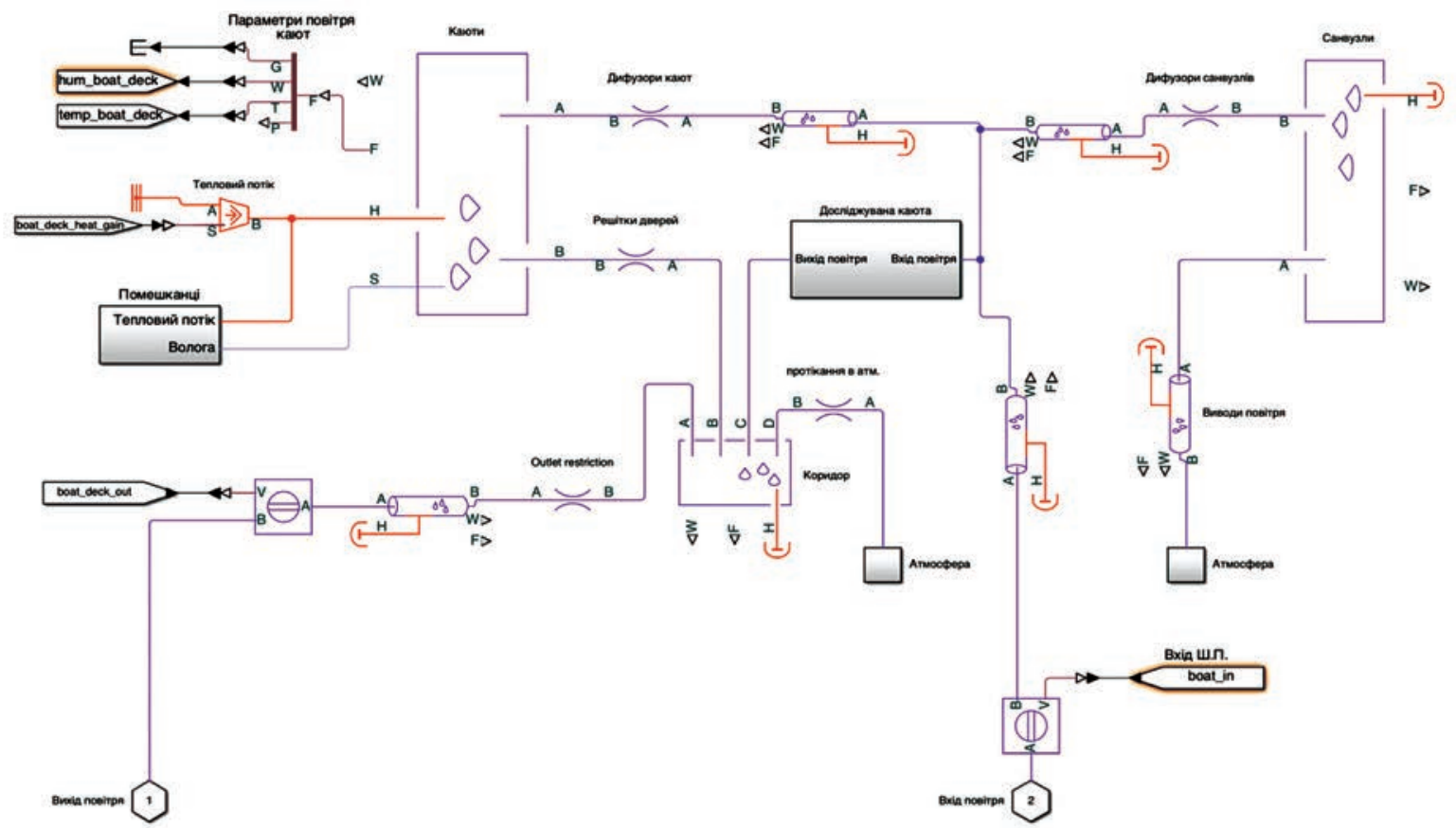

Рис. 2. Модель палуби газовозу LPG/C “Еpic Corsica” з виділеною досліджуваною каютою

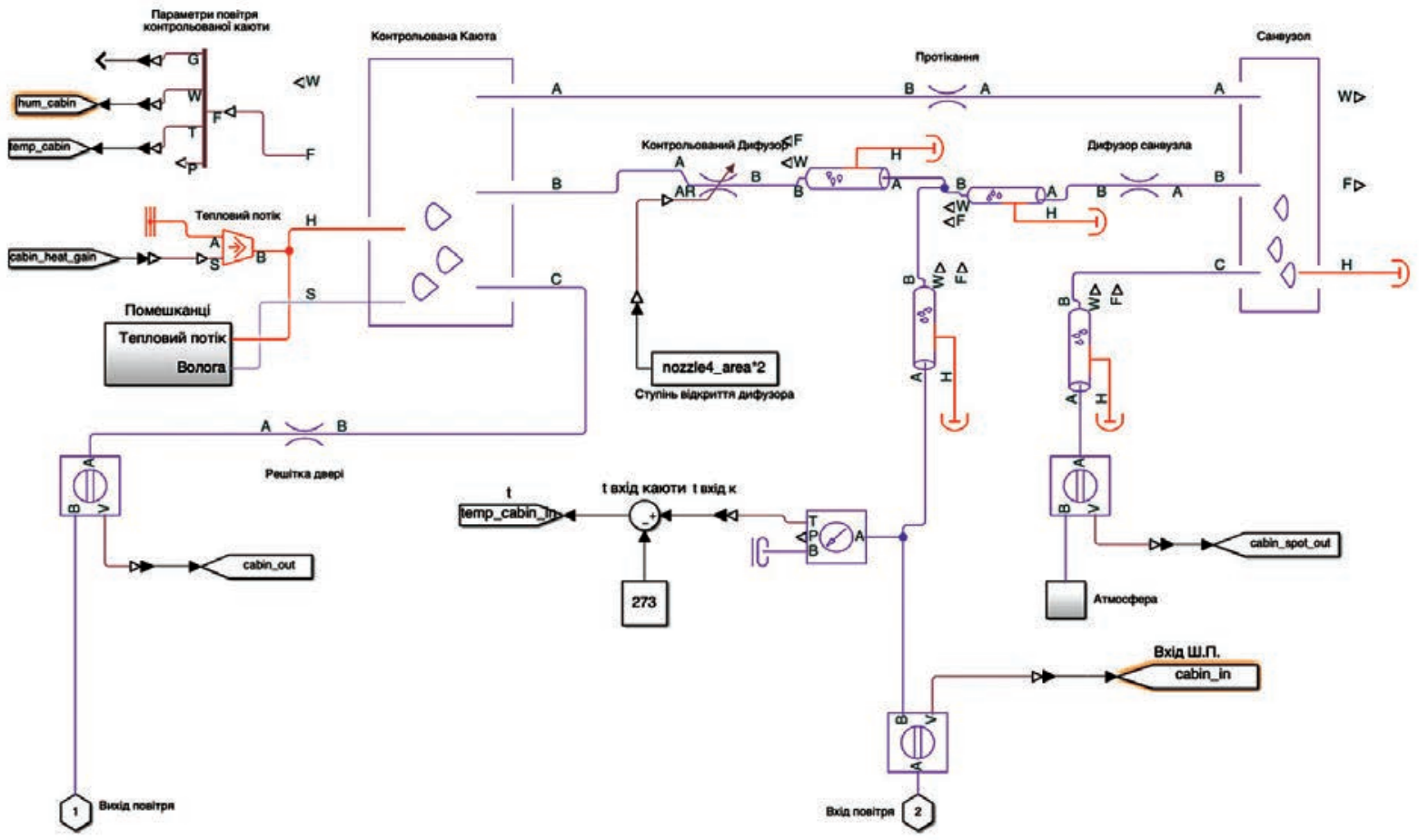

Рис. 3. Модель досліджуваної каюти з суміжним санвузлом 


\section{АВТОМАТИЗАЦІЯ ТА КОМП'ЮТЕРНО-ІНТЕГРОВАНІ ТЕХНОЛОГІЇ №2 - 2021}

Перевірка адекватності моделі здійснювалась у два етапи. На першому етапі проєктні масові витрати повітря кожної з палуб та досліджуваної каюти були порівняні з розрахованими (табл. 2). Отримані відхилення в межах $1 \%$ свідчать про коректне моделювання розподілення припливного повітря. На другому етапі перевірки були побудовані криві розгону температури (рис. 7) та відносної вологості (рис. 8) внутрішнього повітря приміщень надбудови при ступеневому збільшенні об'ємної витрати охолоджувального повітря. Як початкові умови були використані температура $35^{\circ} \mathrm{C}$ й вологість $70 \%$ для зовнішнього та внутрішнього повітря приміщень надбудови при нульовій початковій об'ємній витраті охолоджу- вального повітря. Такі ж умови були використані під час розрахунку системи кондиціювання на етапі проєктування. Такі умови відповідають перебуванню судна у тропічних широтах протягом тривалого часу із зупиненим кондиціюванням повітря надбудови. Ступеневим впливом прийнято миттєве збільшення об'ємної витрати охолоджувального повітря 3 нуля до проєктного значення $1.663 \mathrm{~m}^{3} / \mathrm{c}$. У сталому режимі температура припливного повітря на виході 3 випарника досягає $15^{\circ} \mathrm{C}$, а на виході з вентилятора $-17^{\circ} \mathrm{C}$, що відповідає проєктним даним суднового кондиціонера. Тепловий потік від навколишнього середовища до приміщень надбудови вважався постійним та рівним проєктному згідно з таблицею 1.
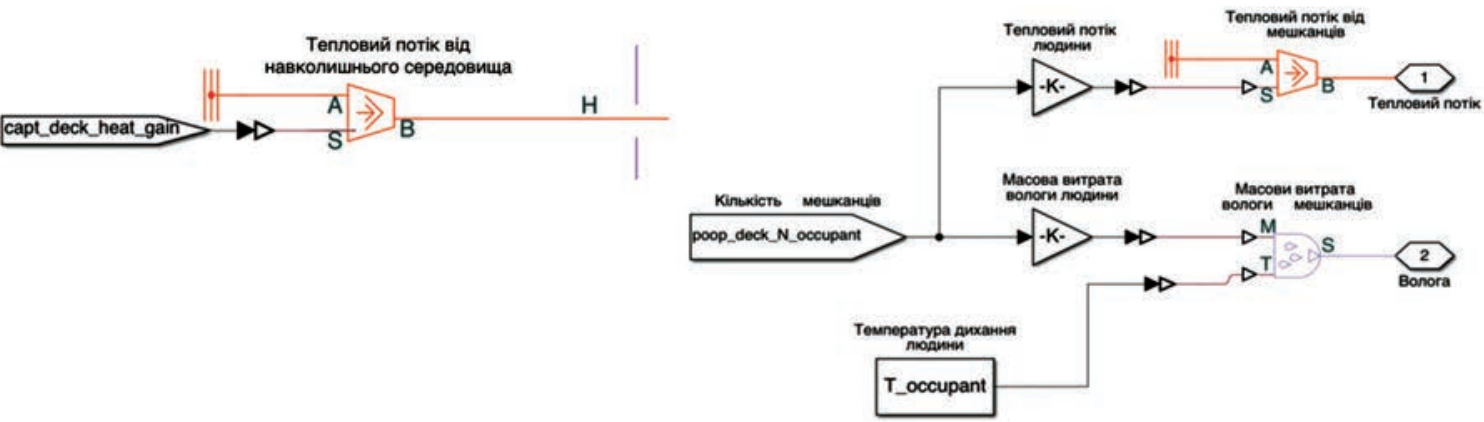

a)

б)

Рис. 4. Моделі тепло- та масообміну приміщення: а) з навколишнім середовищем; б) з мешканцями

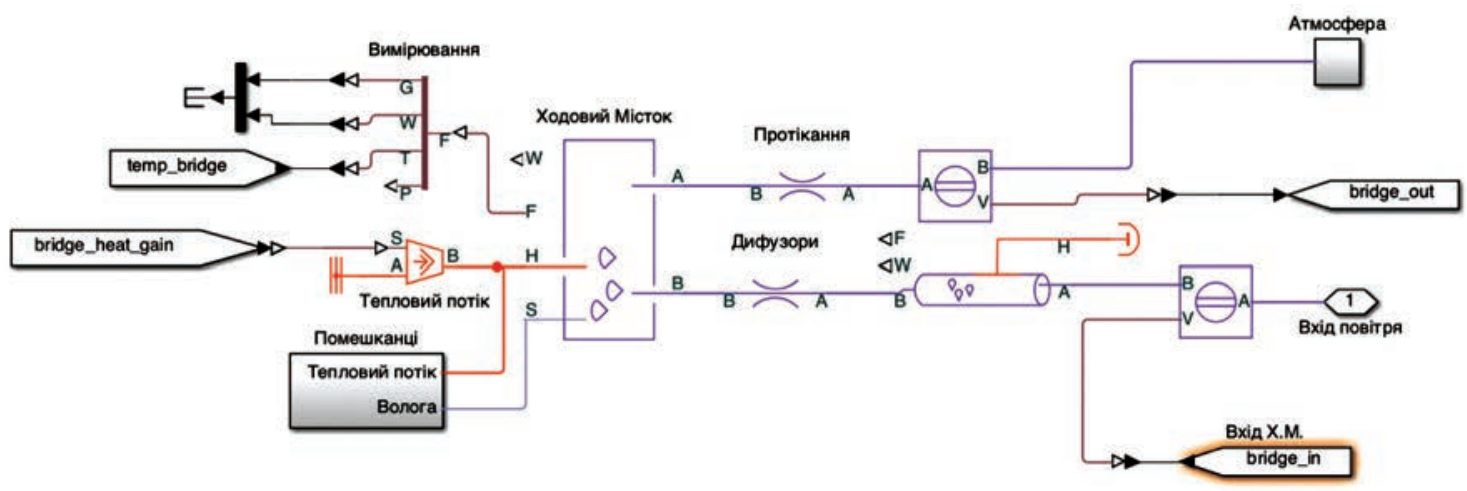

Рис. 5. Модель ходового містка

Таблиця 2. Результати моделювання повітрообміну моделі порівняно з проєктом

\begin{tabular}{|c|c|c|c|}
\hline Смність & $\begin{array}{c}\text { Просктна об'ємна витрата } \\
\text { повітря, } \mathbf{m}^{\mathbf{3}} / \mathbf{\Gamma}\end{array}$ & $\begin{array}{c}\text { Розрахована об'ємна витрата } \\
\text { повітря, } \mathbf{~}^{\mathbf{3}} / \mathbf{\Gamma}\end{array}$ & Відхилення, \% \\
\hline Ходовий Місток & 915 & 917.64 & 0.29 \\
\hline Капітанська палуба & 1115 & 1117.08 & 0.19 \\
\hline Шлюпочна палуба & 1178 & 1180.44 & 0.21 \\
\hline Кормова палуба & 2779 & 2771.64 & -0.26 \\
\hline Досліджувана каюта & 150 & 148.68 & -0.88 \\
\hline
\end{tabular}




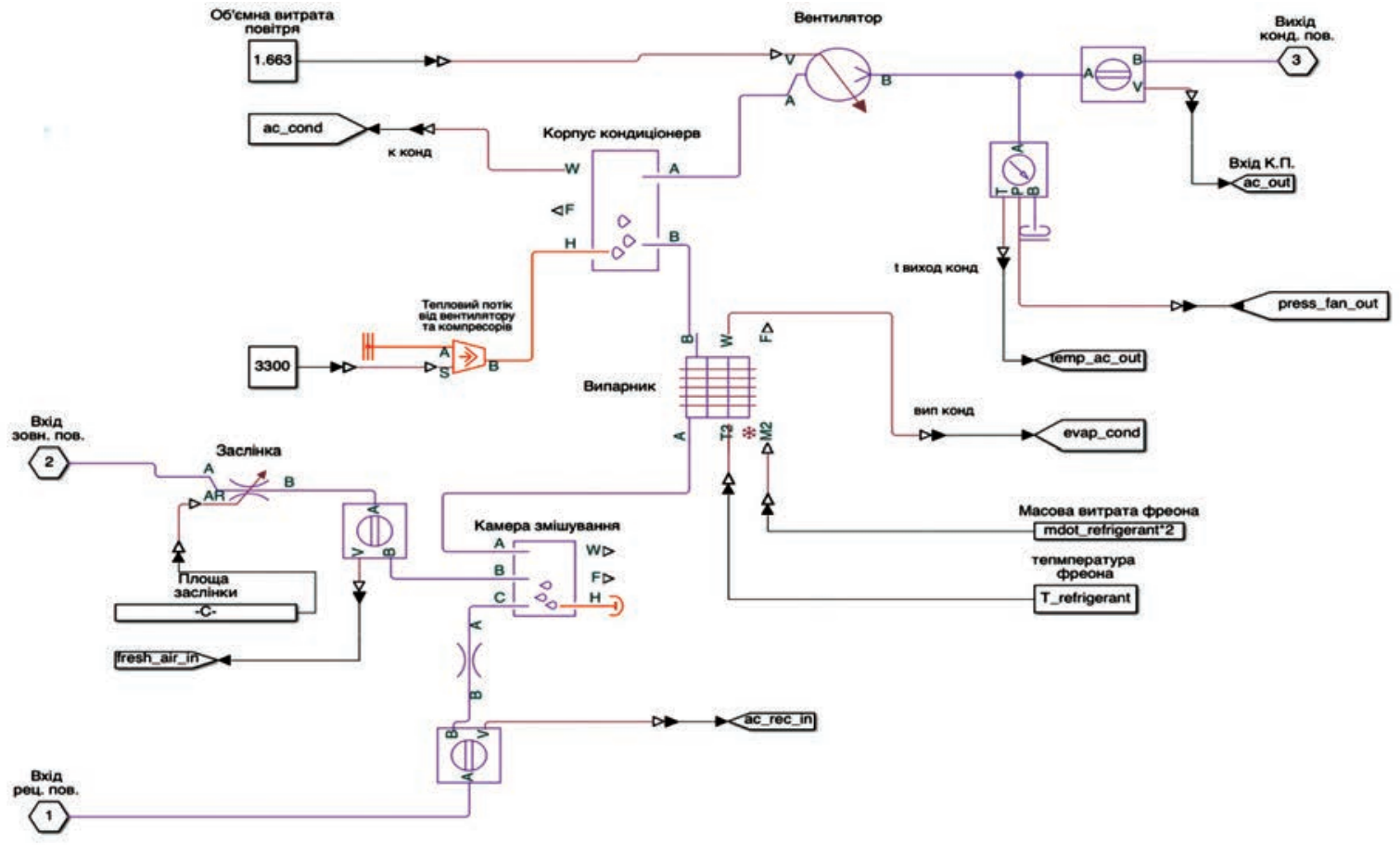

Рис. 6. Модель установки кондиціювання повітря

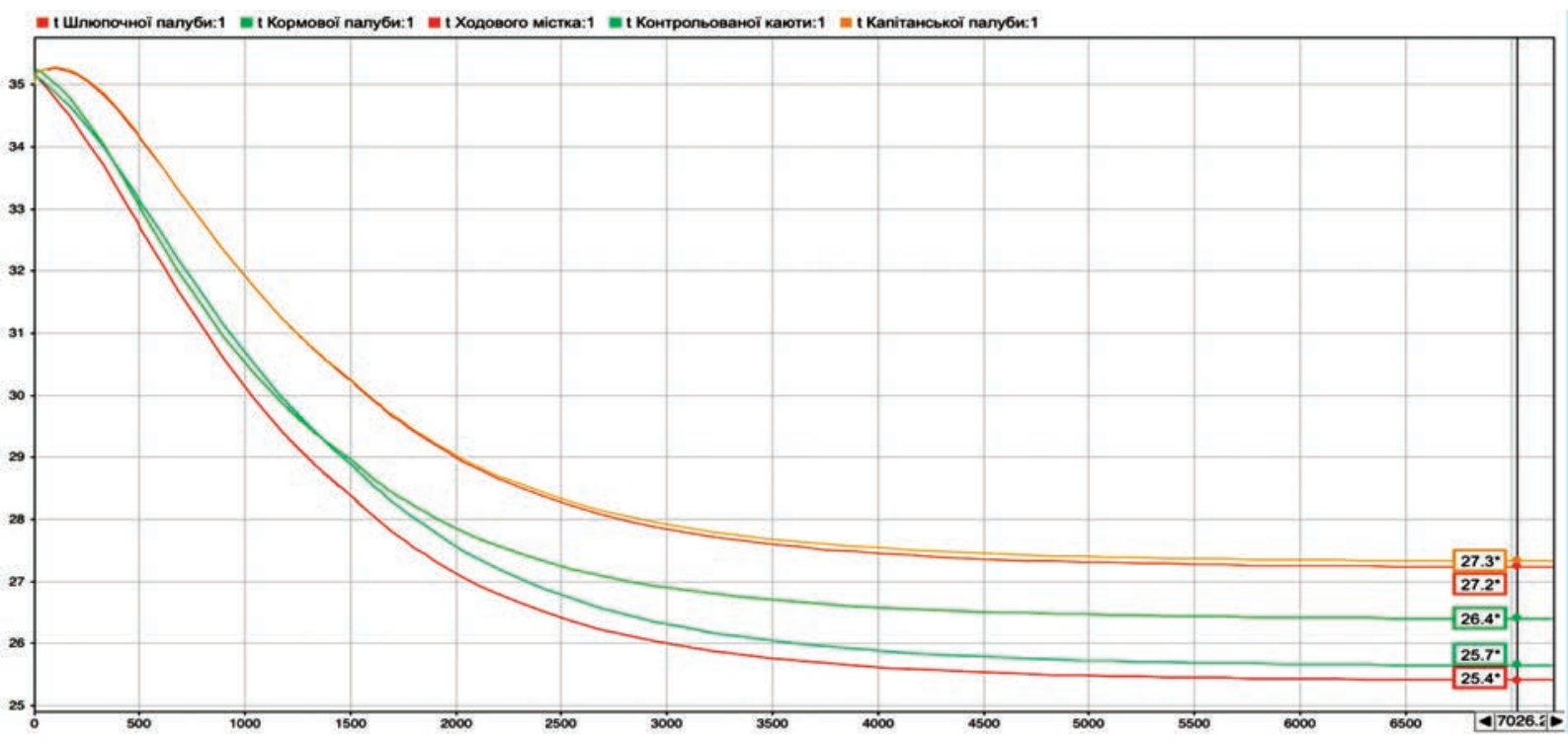

Рис. 7. Криві розгону температури повітря трьох палуб, ходового містка та контрольованої каюти

У сталому режимі середня температура приміщень надбудови досягає $26.4^{\circ} \mathrm{C}$, що на $0.6^{\circ} \mathrm{C}$ менше, ніж проєктні $27^{\circ} \mathrm{C}$, а абсолютні значення відхилень температур окремих палуб та досліджуваної каюти не перевищують $1.6^{\circ} \mathrm{C}$ від проєктної.

Середня відносна вологість повітря надбудови у сталому режимі досягає 51.8\% при проєктній $-50 \%$, а абсолютні значення відхилень відносної вологості окремих палуб від проєктних не перевищують $3.8 \%$. Відносна вологість повітря досліджуваної каюти у сталому режимі на 5.8\% більша, ніж проєктна.

Отримані результати моделювання свідчать про задовільну точність моделі та їі адекватність.

Одним з перспективних застосувань синтезованої моделіє дослідження динамікигазового складуповітря у надбудові. Досліджуване судно перевозить пропілен, гранична безпечна концентрація (TLV) якого становить 500 ppm. Згідно з Міжнародним кодексом з будування та обладнання суден, що перевозять скраплені 


\section{АВТОМАТИЗАЦІЯ ТА КОМП'ЮТЕРНО-ІНТЕГРОВАНІ ТЕХНОЛОГІЇ}

гази наливом (IGC Code), стаціонарна газовимірювальна система у надбудові налаштовується на спрацювання при досягненні концентрації 30\% від нижньої межі вибуховості, яка для пропілену дорівнює 2\% (або 20000 ррm). Таким чином, у разі аварійного витоку вантажу газовимірювальна система спрацює лише при концентрації забруднювача 6000 ppm, яка перевищує безпечну у 12 разів.
На рис. 9 представлено криву розгону вмісту пропілену у досліджуваній каюті при ступеневому збільшенні концентрації забруднювача у зовнішньому повітрі до 3000 ppm у момент часу 1500 секунд 3 початку відліку. Крива розгону була розрахована для об'ємної частки зовнішнього повітря 30\% при повністю відкритих дифузорах припливного повітря в усіх приміщеннях та повністю відкритих вентиля-

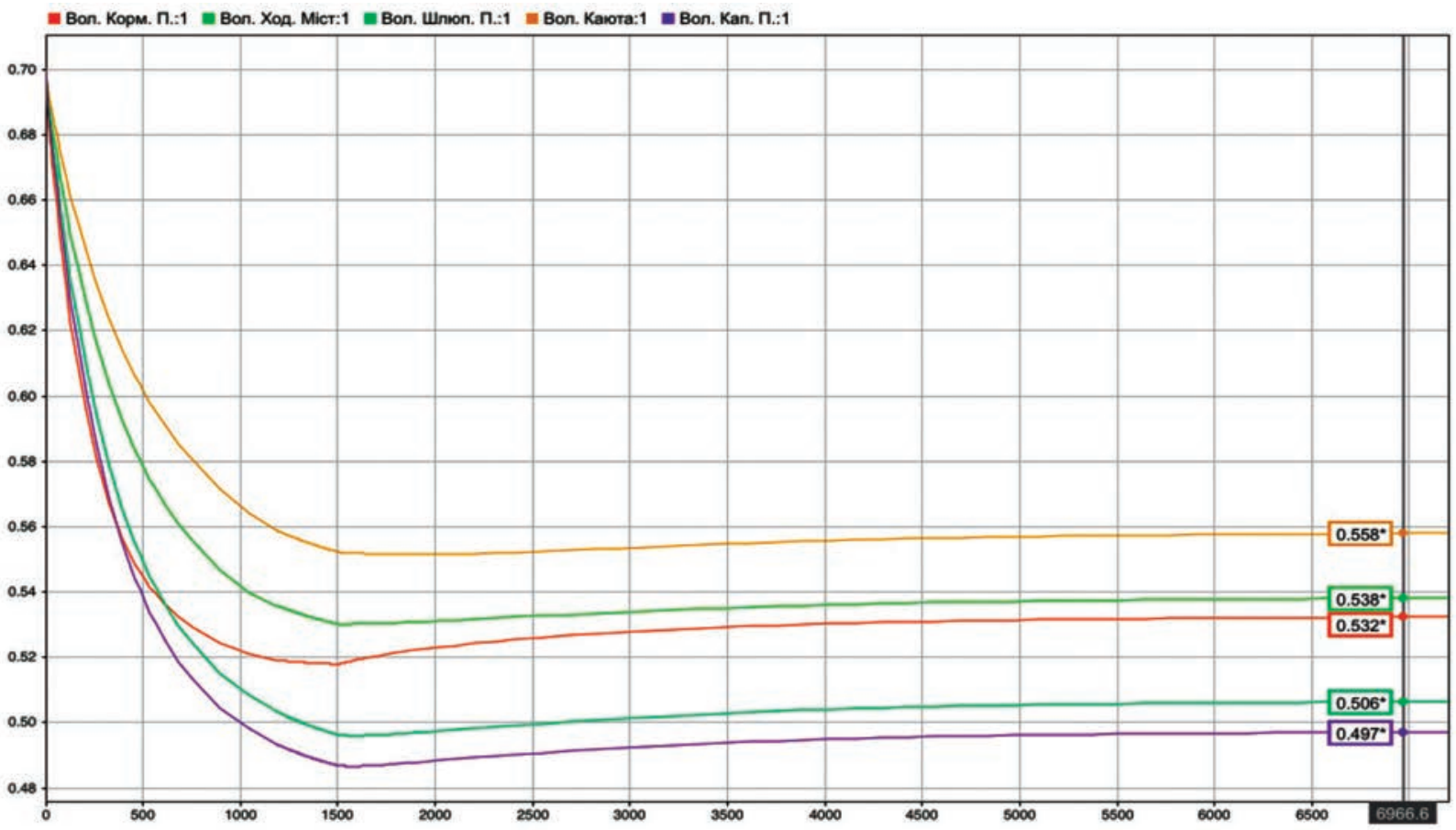

Рис. 8. Криві розгону відносної вологості повітря трьох палуб, ходового містка та контрольованої каюти

Бонц. забр. прим:1

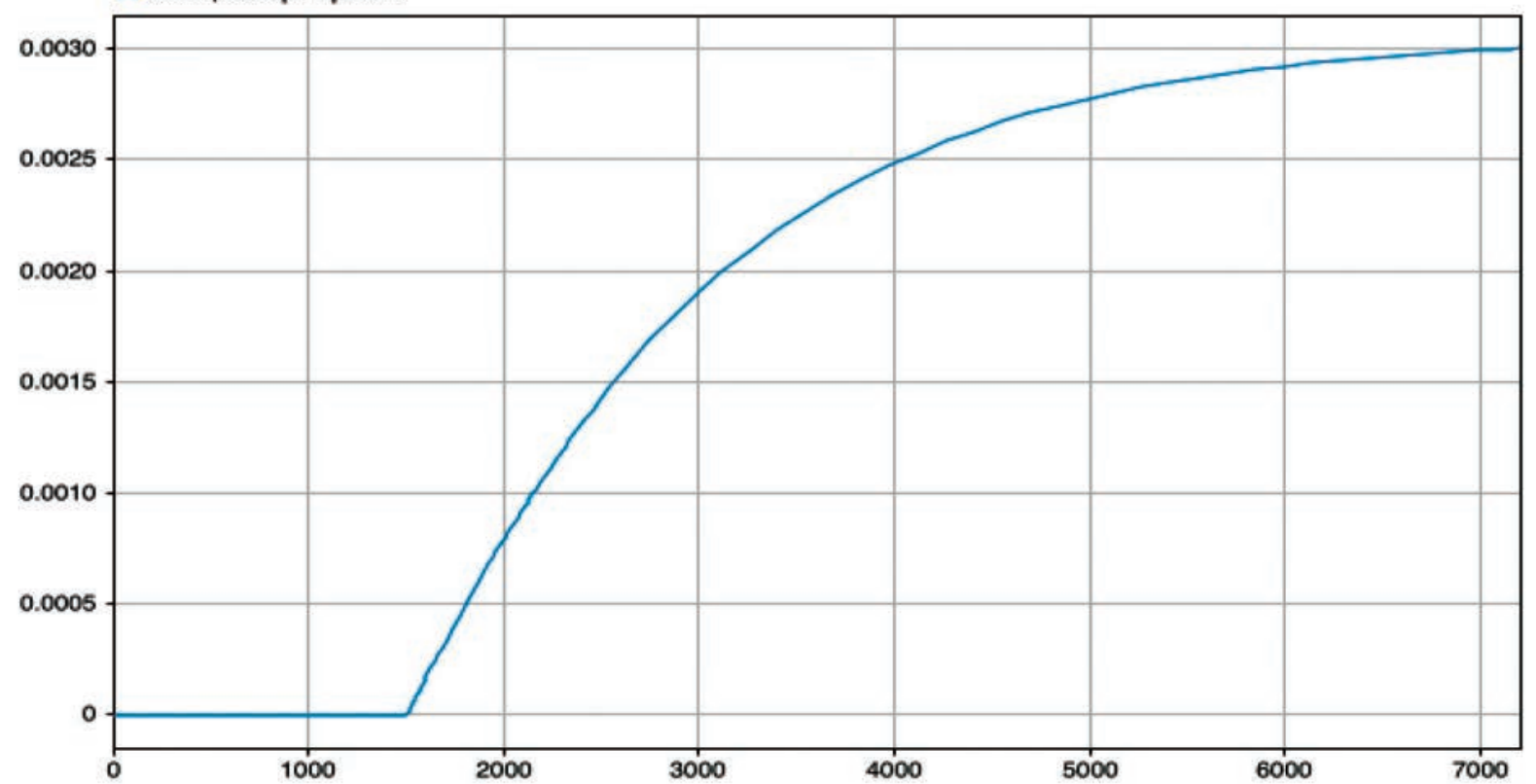

Рис. 9. Крива розгону концентрації пропілену у досліджуваному приміщенні при ступеневому збільшенні концентрації забруднювача у зовнішньому повітрі 
ційних отворах у приміщеннях відкритого типу. Такі параметри моделі відповідають нормальній експлуатації аварійній ситуації, коли незначне пошкодження вантажної системи танкера спричиняє несподіваний викид вантажу малої інтенсивності.

За результатами моделювання встановлено, що концентрація забруднювача у повітрі досліджуваної каюти досягає граничної безпечної концентрації за 3 хвилини. Динаміка концентрації забруднювача дозволяє використовувати двопозиційну систему короткострокової герметизації надбудови для захисту екіпажу від впливу випарів вантажу.

\section{РЕЗУЛЬТАТИ}

У ході дослідження здійснено структурну ідентифікацію об'єкта керування. Проаналізовано наявні математичні моделі, підходи й системи моделювання мікроклімату. Запропоновано методику моделювання на базі підсистеми вологого повітря програмного пакету Matlab-Simulink 3 використанням проєктної документації центральної системи кондиціювання та креслень надбудови. Методику застосовано до синтезу моделі мікроклімату надбудови судна-газовозу. У результаті моделювання були розраховані криві розгону середньої температури та середньої вологості повітря приміщень надбудови судна, показана адекватність отриманої моделі.

\section{ОБГОВОРЕННЯ ОТРИМАНИХ РЕЗУЛЬТАТІВ}

Завдяки своїй універсальності методика дозволяє створювати моделі мікроклімату надбудови будьяких суден та досліджувати ефективність забезпечення колективної безпеки й комфортності екіпажу, роз- робляти системи герметизації приміщень й фільтрації внутрішнього повітря й відповідні системи автоматичного керування.

Моделі, синтезовані з використанням запропонованої методики, потребують підтвердження адекватності шляхом проведення натурного експерименту на модельованому судні з вимірюванням динаміки температури, вологості повітря приміщень.

Подальше вдосконалення методики передбачає врахування теплоємності та теплопередачі огороджувальних поверхонь приміщень, що дозволить моделювати процеси тепло- та масопередачі у повітрі суднової надбудови у всьому діапазоні параметрів зовнішнього повітря та на всіх режимах роботи суднової СКП.

\section{ВИСНОВКИ}

Результатом дослідження є заснована на судновій проєктній документації методика моделювання надбудови судна як багатоємнісного об'єкта керування каналами температури, вологості та газового складу повітря приміщень.

Була проведена апробація методики та синтезована модель надбудови судна-газовозу, яка надає можливість досліджувати динаміку газового складу у надбудові й розробляти системи колективної безпеки для захисту екіпажів від витоку випарів вантажу та інших забруднювачів.

Отримані результати моделювання дозволяють виявити характеристики досліджуваної системи, які не були враховані при проєктуванні та побудові судна, але $\epsilon$ важливими для забезпечення безпеки екіпажу згідно з новітніми дослідженнями та нормами.

\section{REFERENCES}

[1] Sun-Sook Kim, Yoon-Kyung Kang, Geun-Young Doe, Yun-Gyu Lee (2008) Comparison of indoor air quality on a passenger ship and a chemical ship. Korea Maritime University. Retrived from: https://www.isiaq.org/docs/papers/490.pdf

[2] A.D. Webster G.L. Reynolds (2005) Indoor Air Quality on Passenger Ships Hdb Env Chem Vol. 4, Part H (2005): P. $335-349$. Retrived from: https://doi.org/10.1007/b107251

[3] Kennedy, RD. (2019) An investigation of air pollution on the decks of 4 cruise ships. A report for Stand.earth, January 24.

[4] Sun Sook Kim a, Yun Gyu Lee (2010) Field measurements of indoor air pollutant concentrations on two new ships.

[5] Sarka Langer, Cecilia Österman, Bo Strandberg, Jana Moldanová, Håkan Fridén (2020) Impacts of fuel quality on indoor environment onboard a ship: From policy to practice, Transportation Research Part D: Transport and Environment, Volume 83, Retrived from: https://doi.org/10.1016/j.trd.2020.102352.

[6] Golikov, V. A. (1999) Nauchnye osnovi upravleniya mikroklimatom sudna. Odessa: OGMA.

[7] Khodarina K. V. (2013) Obespechenie komfortnykh usloviy mikroklimata obitaemykh pomeshcheniy morskikh sudov: dis. na soisk. uch. step. kand. tekhn. nauk: spets. 05.22.20 "Ekspluatatsiya i remont sredstv transporta"

[8] Ryzhov, A. \& Ouerdane, Henni \& Gryazina, Elena \& Bischi, Aldo \& Turitsyn, K.. (2018). Model predictive control of indoor microclimate: Existing building stock comfort improvement. Energy Conversion and Management. Retrived from: https://doi.org/179. 10.1016/j.enconman.2018.10.046.

[9] Schijndel, Jos. (2007). Integrated heat air and moisture modeling and simulation. Journal of The Acoustical Society of America - J ACOUST SOC AMER.

[10] Holikov V. A., Bilyi V. A. (2021) Modeliuvannia teplo-masoobminnykh protsesiv u povitri sudnovykh prymishchen. MPP\&O-2021 : tezy dop. III Mizhnar. nauk.-prakt. konf., m. Odesa, $29-30$ kvit. 2021 r. / Odeskyi natsionalnyi morskyi universytet. Odesa. P. 297-302. Retrived from: https:// http://dx.doi.org/10.13140/RG.2.2.19286.40006

\section{СПИСОК ВИКОРИСТАНОЇ ЛІТЕРАТУРИ}

[1] Sun-Sook Kim, Yoon-Kyung Kang, Geun-Young Doe, Yun-Gyu Lee (2008) Comparison of indoor air quality on a passenger ship and a chemical ship. Korea Maritime University. URL: https://www.isiaq.org/docs/papers/490.pdf. 


\section{АВТОМАТИЗАЦІЯ ТА КОМП'ЮТЕРНО-ІНТЕГРОВАНІ ТЕХНОЛОГІЇ №2 2021}

[2] A.D. Webster G.L. Reynolds (2005) Indoor Air Quality on Passenger Ships Hdb Env Chem Vol. 4, Part H (2005): $335-349$. DOI 10.1007/b107251.

[3] Kennedy, RD. (2019) An investigation of air pollution on the decks of 4 cruise ships. A report for Stand.earth, January 24, 2019.

[4] Sun Sook Kim a, Yun Gyu Lee (2010) Field measurements of indoor air pollutant concentrations on two new ships.

[5] Sarka Langer, Cecilia Österman, Bo Strandberg, Jana Moldanová, Håkan Fridén (2020) Impacts of fuel quality on indoor environment onboard a ship: From policy to practice, Transportation Research Part D: Transport and Environment, Volume 83, 2020. URL: https://doi.org/10.1016/j.trd.2020.102352.

[6] Голиков В.А. (1999) Научные основы управления микроклиматом судна. Одесса : ОГМА.

[7] Ходарина К.В. (2013) Обеспечение комфортных условий микроклимата обитаемых помещений морских судов : дис. ... канд. техн. наук : 05.22.20, «Эксплуатация и ремонт средств транспорта».

[8] Ryzhov A. \& Ouerdane Henni \& Gryazina Elena \& Bischi, Aldo \& Turitsyn K. (2018). Model predictive control of indoor microclimate: Existing building stock comfort improvement. Energy Conversion and Management. 179. 10.1016/j. enconman.2018.10.046.

[9] Schijndel, Jos. (2007). Integrated heat air and moisture modeling and simulation. Journal of The Acoustical Society of America - J ACOUST SOC AMER.

[10] Голіков В. А., Білий В. А. (2021) Моделювання тепло-масообмінних процесів у повітрі суднових приміщень. МРP\&O-2021 : тези доп. III Міжнар. наук.-практ. конф., м. Одеса, 29-30 квіт. 2021 р. / Одеський національний морський університет. Одеса. С. 297-302. URL: https://http://dx.doi.org/10.13140/RG.2.2.19286.40006.

(C) Білий В. А., Голіков В. А. Дата надходження статті до редакції: 08.06.2021 Дата затвердження статті до друку: 29.06.2021 